A complete list of Working

Papers on the last page

No. 10,1977

\title{
APPROACHES TO THE THEORY OF CAPITAL \\ COST: AN EXTENSION
}

by

Jan Södersten

March, 1977

This is a preliminary paper. It is intended for private circulation, and should not be quoted or referred to in publications without permission of the author. Comments are welcome. 


\section{Approaches to the theory of capital cost: An extension}

1. The problem

In a recent issue of this Journal ${ }^{1)}$, Villy Bergström demonstrates how the cost of capital to a firm maximizing stockholders wealth may be expressed as a weighted average of the cost of equity and the cost of debt, with due adjustment to the tax laws.

Bergström's interest is confined to the profit taxes paid by the firm, and he consequently abstracts from the tax situation of the shareholders. This leads, inter al, to the implicit conclusion that the way of obtaining equity capital - through the retention of earnings or through the issue of new shares - makes no difference to the before tax cost of capital. This is clearly unrealistic.

The common view that retained earnings are a less expensive source of equity capital than is the issue of new shares, can, however, easily be demonstrated within Bergström's theoretical framework. In this note this is done by including taxes paid directly by the shareholders - personal income tax on dividends and capital gains tax into the analysis. ${ }^{2)}$ This approach also makes it possible to identify the effects on capital cost of different measures to reduce the so called double taxation of dividends, current1y in use in many countries.

\section{Personal taxes and capital cost}

By his equation (1), Bergström follows the usual procedure of stating the value of the firm as the present value of the expected future cash flow to the stockholders. In this note, the same approach is followed, but cash flow will be defined net of all taxes, $i$ e net of profit tax, personal income tax on dividends and capital gains tax. Inclusion of personal taxes also necessitates an explicit treatment of the issuing of new shares by the firm. To start with, I will simply assume that the firm at time $t$ raises the amount $N(t)$ from the shareholders.

1) $1976: 3$.

2) It should be mentioned that personal taxes have been introduced into models of stock valuation before, for instance by Stapleton [1972] and King [1974], mainly to study the effects of financial policies on the firm's stock value or to derive criteria for the firm's optimal financial policy. 
Now, let us proceed on the assumption that the firm distributes $U(t)$ at time $t$ and that dividends are taxed with the shareholders in the same way as capital income from other sources. All shareholders are assumed to face the same marginal rate of income tax, $T$.

Let me then introduce a capital gains tax. If $J(t)$ stands for the value of the firm's (a11) shares, then $\frac{d J(t)}{d t}$ is the capital gain (or loss) at time t. I will follow a by now established procedure by assuming that this capital gain is taxed at a rate $\alpha \mathrm{T}$, on an accruals basis. ${ }^{1)}$ Here $\alpha$ is that fraction of each dollar of capital gain that must be declared as taxable income. Assuming that the amount raised by the firm by issuing new shares, $N(t)$, is deductible in the tax assessment, the amount of capital gains tax paid at time $t$ by shareholders will be

$\alpha \mathrm{T}\left[\frac{\mathrm{dJ}(\mathrm{t})}{\mathrm{dt}}-\mathrm{N}(\mathrm{t})\right]$

Considering the personal income tax on dividends, payments to the firm due to new issues and the capital gains tax, the cash flow accruing to the shareholders at time $t$ may be written

$U(t)(1-T)-N(t)-\alpha T\left[\frac{d J(t)}{d t}-N(t)\right]$

Now, the value of the firm from the stockholders' point of view is the discounted value of the future, expected cash flow net of tax, as expressed by (1). The objective function supposed to be maximized by the firm is then

$J(v)=\int_{t=v}^{\infty}\left\{U(t)(1-T)-N(t)-\alpha T\left[\frac{d J(t)}{d t}-N(t)\right]\right\} e^{-k(1-T)(t-v)} d t$.

Cash flow is discounted by $\mathrm{k}(1-\mathrm{T})$, reflecting the marginal individual income tax rate and the (before tax) yield on alternative investments.

1) In practice capital gains are taxed at the time of realization. However, a given rate of tax on a realized capital gain can always be transformed into an effective rate on the accrued gain. For a penetrating discussion, see Bailey [1969] and Lintner [1962]. 
Using the definition of the derivative of $J(v)$ with respect to the lower limit of integration, (2) may be written ${ }^{1)}$

$J(v)=\int_{t=v}^{\infty}\left[\frac{U(t)(1-T)}{1-\alpha T}-N(t)\right] e^{-\frac{k(1-T)}{1-\alpha T}(t-v)} d t$.

Our next task will be to define $U(t)$ and $N(t)$. The neoclassical theory of the firm used by Bergström, implies that dividends are determined residually. In other words, the firm distributes whatever remains of its cash flow, once gross investment, debt services and profit taxes are paid for. The issuing of new share capital, then, means a ceteris paribus improvement in the firm's ability to distribute. To simplify exposition, let $U^{0}(t)$ represent Bergström's expression for dividends (his equation (1)). Then

$U(t)=U^{0}(t)+N(t)$

taking new issues into account.

Comparing equations (3) and (4), the issuing of new share capital may be seen to affect the value of the firm in two ways. First, there is according to (3) a direct reduction in capital value equal to the present value of the amounts raised by the firm, and second, there is an increase in value due to the ceteris paribus raise in dividends, as expressed by (4). These opposing effects do not cancel, however, unless $\alpha=1$, $i$ e capital gains are taxed at the same rate as dividend income. In fact, here lies the ultimate reason for the explicit inclusion of new issues into the analysis.

As for $N(t)$, finally, I will simply assume that the firm has a policy of financing a given fraction $n$ of its net investment by new issues. This means that

$N(t)={ }_{n} P_{K}(t)[I(t)-\delta K(t)]$

1) Taking the derivative of $J(v)$ with respect to $v$, yields

$\frac{\mathrm{dJ}(\mathrm{v})}{\mathrm{dv}}=\mathrm{kJ}(\mathrm{v})-\left\{\mathrm{U}(\mathrm{v})(1-\mathrm{T})-\mathrm{N}(\mathrm{v})-\alpha \mathrm{T}\left[\frac{\mathrm{dJ}(\mathrm{v})}{\mathrm{dv}}-\mathrm{N}(\mathrm{v})\right]\right\}$

i e

$\frac{\mathrm{d} J(\mathrm{v})}{\mathrm{dv}}=\frac{\mathrm{k}}{1-\alpha \mathrm{T}} \mathrm{J}(\mathrm{v})-\left[\frac{\mathrm{U}(\mathrm{v})(1-\mathrm{T})}{1-\alpha \mathrm{T}}-\mathrm{N}(\mathrm{v})\right]$.

Equation (3) above is one solution to this differential equation. 
where $P_{K}(t)[I(t)-\delta K(t)]$ is the firm's net investment at time $t$. This assumption, in fact, is analogous to that used by Bergström as to debt policy, namely that the firm finances a constant proportion $h$ of its capital growth by borrowing ${ }^{1)}$. Obviously then, $(1-h-n)$ is that portion of the firm's investments financed by retained earnings. It should be pointed out that by these assumptions the volume of investment will be restricted at certain points in time by the fact that dividends in my formulation cannot reasonably be negative. ${ }^{2)}$

Having defined $U(t)$ and $N(t)$, insertion of (4) and (5) into (3) yields the value of the firm in the terms used by Bergström and with due adjustment to (i) profit taxes, (ii) personal income tax on dividends, (iii) accrued capital gains tax and (iv) issues of new share capital. At this point the analysis may be carried on in the manner demonstrated by Bergström. Therefore, to avoid repetition, I will just state the results, focusing on the effects of personal taxes on capital $\cos t$.

To simplify exposition, I will rule out the possibility to defer taxes through accelerated depreciation, and furthermore, assume a11 prices, including the shadow prices of capital goods, debt services and depreciation charges to stay constant. Given these assumptions Bergström's expression for capital cost (equation (13)) becomes

$r=i h+\frac{k}{1-\tau}(1-h)$

Here, $i$ is the cost of debt and $h$ is the firm's debt ratio, $k$ is stockholders' required rate of return net of profit tax (personal taxes are not considered) and $\tau$ is the rate of profit tax. Thus, capital cost is a weighted average of the cost of debt and the (before tax) cost of equity.

Introducing, then, personal taxes in the manner discussed above and letting $\mathrm{k}(1-\mathrm{T})$ represent stockholders' required rate of return net of all taxes, capital cost turns out

$r^{*}=i h+\frac{k(1-T) n}{1-\tau-T(1-\tau)}+\frac{k(1-T)(1-h-n)}{1-\tau-\alpha T(1-\tau)}$.

1) Bergström assumes that the firm finances a constant proportion $h$ of its gross investments by debt and, further, that the rate of amortization of this debt coincides with the rate of physical depreciation of the firm's capital stock. Abstracting from changes in the market value of the debt, these assumptions imply that the proportion of debt in the firm's net capital growth - i e net investment - also equals $h$.

2) Cf Bergström, p 440. 
Recalling that $n$ represents the portion of the firm's investments financed by new issues and $(1-h-n)$ the portion financed by retained earnings, the interpretation of (7) is straightforward: Capital cost is a weighted average of the cost of debt, the cost of new issues and the cost of retained earnings. The cost of new issues, in turn, may be seen as stockholders' required rate of return net of tax, $k(1-T)$, expanded by a factor allowing for the total tax burden (corporate and persona1) on distributed profits. Analogously, the cost of retained earnings is stockholders' required rate of return increased to allow for what intuitively may be seen as the total tax burden on retained profits, $i$ e the corporate tax rate, $\tau$, and the tax rate on capital gains, $\alpha \mathrm{T}$.

It may be noted that $\alpha=1$, $i$ e full shareholder taxation of capital gains, would cause (7) to collapse into (6), used by Bergström. If instead $\alpha<1$, $i$ e capital gains are taxed at a lower rate than personal income, retained earnings will make up a less expensive source of equity capital than new issues. The model analysed here thus provides a rational for the firms' apparent preference for financing investments out of retained earnings in terms of the tax differential - existing in most countries between capital gains and dividend income. ${ }^{1)}$

\section{Mitigating double taxation}

This reformulation of Bergström's analysis is of obvious importance to much discussed questions about the workings of the investment process, including the efficiency of the allocation of resources within the corporate sector and between the corporate and noncorporate sectors of the economy. ${ }^{2)}$ In this context, it is interesting to note that several countries have introduced measures that in effect tend to reduce the tax differential between capital gains and dividend income. This is accomplished by partially eliminating the "double taxation" of dividends, characterizing the system of profit taxation analysed above.

For this purpose, two different methods have been employed. One, referred to as the imputation credit system, places a reduction of the total tax burden on distributed profits at the shareholder level, while the other, called the split rate system, implies the use of a lower corporate tax rate for distributed earnings. ${ }^{3)}$ The effects on capital cost of these methods will be studied below.

1) Baumol et al [1970] in their empirical study of earnings retention and growth of firm found the rate of return on new equity capital to be very much higher than the rate of return on either ploughback or new debt. These authors, however, ran their explanation to these findings solely in terms of the transaction costs involved with different sources of finance.

2) Cf Bailey [1969], Break [1969] and McLure [1975].

3) Cf Hammer [1975] for a penetrating discussion. 
The split rate system, used e $g$ in Japan and West Germany, can be described as follows: Let $\tau^{\mathrm{d}}$ and $\tau^{\mathrm{r}}$ be the corporate tax rates on distributed and retained profits, respectively, and $\Pi(t)$ be the firm's total taxable income. Assume as before, that the firm distributes $U(t)$ to the shareholders. Since $U(t)$ is defined net of corporation tax, then $U(t) / 1-\tau{ }^{d}$ represents the firm's distributed profits before tax and $I I(t)-U(t) / 1-\tau{ }^{d}$ retained profits, also before tax. The corporation tax liability, due at time $t$, may then be expressed as

$$
\begin{aligned}
& S(t)=\frac{\tau^{d} U(t)}{1-\tau^{d}}+\tau^{r}\left[\Pi(t)-\frac{U(t)}{1-\tau^{d}}\right]= \\
& =\tau^{r} \Pi(t)-\left(\tau^{r}-\tau^{d}\right) \frac{U(t)}{1-\tau} d
\end{aligned}
$$

making it clear that a reallocation of profits from retention to distribution will reduce the firm's tax payments, provided $\tau^{d}<\tau^{r}$. Using, then, Bergström's definition of $\Pi(t)$ (his equation 2) the effects of the split rate system on stockholders cash flow and the value of the firm may be determined by inserting (8) into (4) and (3).

With the imputation system, used e $g$ in France and United Kingdom, part of the corporation tax paid by the firm on distributed profits is regarded as an advance payment on account of the shareholders eventual income tax liability. Shareholders therefore receive a credit in their income tax assessments for part of the tax already paid by the corporation.

To describe the imputation system in a general way, it is convenient to introduce a parameter s, representing a "rate of tax credit" given to the shareholders. For the interpretation of $\mathrm{s}$, we may note that full compensation to the shareholders for the corporation tax on dividends requires that $s=\tau$, $i$ e the rate of tax credit equals the corporate tax rate. Consequently, $s<\tau$ - as is the case for France and United Kingdom - implies that shareholders are given credit only for part of the corporation tax.

By this system, the dividends received, $U(t)$, would first be "grossed up" to $U(t) /(1-s)$, to represent a corporate pre-tax income behind the dividend. $U(t) /(1-s)$ is then interpreted as an imputed shareholder income, implying an income tax liability of $T \cdot U(t) /(1-s)$. For this amount, however, shareholders would receive a tax credit of $s \cdot U(t) /(1-s)$, reducing the income tax on the dividends to $(\mathrm{T}-\mathrm{s}) \mathrm{U}(\mathrm{t}) /(1-\mathrm{s})$. 
After the deduction of $(\mathrm{T}-\mathrm{s}) \mathrm{U}(\mathrm{t}) /(1-\mathrm{s})$ from the dividends paid by the firm, there remains $U(t)(1-T) /(1-s)$ to the shareholders. The firms objective function with due adjustment to the imputation system therefore becomes

$J(v)=\int_{t=v}^{\infty}\left[\frac{U(t)(1-T)}{(1-\alpha T)(1-s)}-N(t)\right] e^{-\frac{k(1-T)}{1-\alpha T}(t-v)} d t$.

Having introduced the split rate system through expression (8) and the imputation system through expression (3)', the analysis may be carried on in exactly the manner outlined above. Capital cost then becomes

$r *=i h+\frac{k(1-T) n}{\left[1-\tau^{d}-\frac{T-s}{1-s}\left(1-\tau^{d}\right)\right]}+\frac{k(1-T)(1-h-n)}{\left[1-\tau^{r}-\alpha T\left(1-\tau^{r}\right)\right]}$.

The interpretation of (9) is the same as that for (7). Measures to mitigate the double taxation of dividend income, either through an imputation credit system $(s>0)$ at the shareholder level, or through a split rate system $\left(\tau^{d}<\tau\right.$ r $)$ at the corporate level, ceteris paribus, tend to lower the cost of new issues. Neutrality as to the firm's choice between new issues and retained earnings obviously requires that

$\tau^{\mathrm{d}}+\frac{\mathrm{T}-\mathrm{s}}{1-\mathrm{s}}\left(1-\tau^{\mathrm{d}}\right)=\tau^{\mathrm{r}}+\alpha \mathrm{T}\left(1-\tau^{\mathrm{r}}\right)$

which means that the total tax burden on distributed profits (left hand side of (10)) equals what intuitively may be seen as the total tax burden on retained profits. Clearly, fulfillment of condition (10) may be secured not only through a reduction of the total tax burden on dividends, but also through an increase in the rate of tax on capital gains, or on retained profits. 


\section{References}

Bergström, Villy, 1976, Approaches to the Theory of Capital Cost. Scandinavian Journal of Economics, Vo1. 78, pp. 437-456

Bailey, Martin J., 1969, Capital Gains and Income Taxation. In The Taxation of Income from Capital (ed. Arnold C. Harberger \& Martin J. Bailey). Studies in Government Finance. The Brookings Institution. Washington.

Baumol, William J., Heim, Peggy, Malkiel, Burton G. \& Quant, Richard E., 1970, Earnings Retention, New Capital and the Growth of the Firm. Review of Economics and Statistics, Vo1. LII, pp. 345-355

Break, George, F., 1969, Integration of the Corporate and Personal Income Taxes. National Tax Journal, Vo1. XXII, pp. 39-56

Hammer, Richard M., 1975, The Taxation of Income from Corporate Shareholders: Review of Present Systems in Canada, France, Germany, Japan and the U.K. Nationa1 Tax Journa1, Vol. XXVIII, pp. 315-334.

King, Mervin A., 1974, Taxation and the Cost of Capital. Review of Economic Studies, Vo1. XLI, pp 21-35

Lintner, John, 1962, Dividends, Earnings, Leverage, Stock Prices and the Supply of Capital to Corporations. Review of Economics and Statistics, Vo1. XLIV, pp. 243-269.

McLure, Charles E., 1975, The Case for Integrating the Income Taxes. National Tax Journa1, Vo1. XXVIII, pp 257-264

Stapleton, R.C., 1972, Taxes, the Cost of Capital and the Theory of Investment. Economic Journa1, Vo1. 82, pp 1273-1292 